\title{
GAMBARAN PENGETAHUAN DAN SIKAP IBU RUMAH TANGGA TERHADAP PENGGUNAAN ANTIBIOTIK DI DESA KUTA MBELIN KECAMATAN LAU BALENG KABUPATEN KARO
}

\author{
Rini Andarwati \\ Jurusan Farmasi Poltekkes Kemenkes Medan
}

\begin{abstract}
Abstrak
Penggunaan antibiotik, yang sesuai atau tidak sesuai, telah dijelaskan sebagai pendorong utama bagi munculnya peningkatan dan penyebaran resisten antibiotik. Ada beberapa faktor yang mempengaruhi ketepatan penggunaan antibiotik pada masyarakat khususnya ibu rumah tangga. Salah satu faktor yang penting adalah tingkat pengetahuan ibu rumah tangga itu sendiri mengenai antibiotik. Beberapa faktor yang mempengaruhi tingkat pengetahuan tersebut, seperti tingkat pendidikan dari ibu rumah tangga, penjelasan oleh dokter, serta anggapan-anggapan lain yang menimbulkan adanya kesalahan saat mengkonsumsi antibiotik. Tujuan penelitian ini adalah mengetahui gambaran pengetahuan dan sikap ibu rumah tangga terhadap penggunaan antibiotik di Desa Kuta Mbelin Kecamatan Lau Baleng Kabupaten Karo. Metode penelitian ini adalah penelitian survei deskriptif dan tenik pengambilan sampel digunakan adalah teknik simple random sampling. Populasi dalam penelitian ini adalah 250 ibu rumah tangga dan jumlah sampel 130 .Hasil penelitian menunjukkankan bahwa pengetahuan ibu rumah tangga berada dalam kategori baik (41,54\%),pada kategori cukup $(50 \%)$ dan pada kategori kurang $(8,46 \%)$. Sikap ibu rumah tangga berada dalam kategori baik $(65,38 \%)$, pada kategori cukup $(33,84 \%)$, dan pada kategori kurang $(0,78 \%)$.
\end{abstract}

Kata kunci : Pengetahuan, sikap, penggunaan antibiotik

\section{LATAR BELAKANG}

Ada beberapa faktor yang mempengaruhi ketepatan penggunaan antibiotik pada masyarakat khususnya ibu rumah tangga. Salah satu faktor yang penting adalah tingkat pengetahuan ibu rumah tangga itu sendiri mengenai antibiotik. Beberapa faktor yang mempengaruhi tingkat pengetahuan tersebut, seperti tingkat pendidikan dari ibu rumah tangga, penjelasan oleh dokter, serta anggapan-anggapan lain yang menimbulkan adanya kesalahan saat mengkonsumsi antibiotik.

Tingkat pengetahuan masyarakat tetang antibiotik telah diteliti diberbagai daerah. Penelitian yang dilakukan oleh Lim dan Teh (2012) di Putrajaya, Malaysia, menyebutkan bahwa $83 \%$ responden tidak mengetahui bahwa antibiotik tidak bekerja untuk melawan infeksi virus dan $82 \%$ responden tidak mengetahui bahwa antibiotik tidak dapat mengobati batuk dan flu, sementara $82,5 \%$ responden terlihat sangat berhati-hati dengan penggunaan antibiotik yang dapat menyebabkan alergi. Penelitian tersebut juga menyatakan bahwa sekitar setengah dari mereka $(52,1 \%)$ tidak mengetahui bahwa antibiotik dapat menimbulkan banyak efek samping. Beberapa pernyataan dari responden diantaranya adalah tidak masalah menghentikan pemakaian antibiotik ketika gejala telah membaik dan mengkonsumsi sedikit antibiotik dari yang diresepkan dokter akan lebih sehat daripada mengkonsumsi seluruh antibiotik yang diresepkan (Pratama, 2013).

Penelitian yang dilakukan oleh Pulungan (2011) di kota Medan mengenai hubungan tingkat pengetahuan tentang antibiotik dan penggunaannya di kalangan mahasiswa non medis Universitas Sumatera Utara mendapatkan bahwa $77 \%$ mahasiswa non medis USU memiliki tingkat pengetahuan yang tinggi terhadap antibiotik, 18\% mahasiswa non medis USU memiliki tingkat pengetahuan sedang dan hanya hampir 5\% mahasiswa non medis USU yang memiliki pengetahuan yang rendah terhadap penggunaan antibiotik.

Menurut survei awal penulis, tingkat pendidikan di daerah tersebut masih rendah, sehingga menjadi salah satu faktor yang mempengaruhi pengetahuan terhadap antibiotik. Pernyatan-pernyataan yang sering penulis dengar mengenai penggunaan antibiotik antara lain mereka berhenti menggunakan antibiotik setelah tidak merasa sakit lagi atau mereka membeli obat antibiotik sendiri tanpa resep dari dokter karena malas untuk pergi ke dokter.

Oleh karena itu penulis tertarik untuk melakukan penelitian mengenai gambaran pengetahuan dan sikap ibu rumah tangga terhadap penggunaan antibiotik. 


\section{Perumusan Masalah}

Berdasarkan latar belakang tersebut, rumusan masalah dalam penelitian ini yaitu, bagaimana gambaran pengetahuan dan sikap ibu rumah tangga terhadap penggunaan antibiotik di desa Kuta Mbelin Kecamatan Lau Baleng Kabupaten Karo.

\section{Tujuan Penelitian}

Tujuan umum

Untuk mengetahui gambaran pengetahuan dan sikap ibu rumah tangga terhadap penggunaan antibiotik di Desa Kuta Mbelin Kecamatan Lau Baleng Kabupaten Karo.

Tujuan khusus

1. Untuk mengetahui tingkat pengetahuan ibu rumah tangga terhadap penggunaan antibiotik.

2. Untuk mengetahui sikap ibu rumah tangga terhadap penggunaan antibiotik.

\section{METODE PENELITIAN}

\section{Jenis dan Desain Penelitian}

Jenis penelitian yang digunakan pada penelitian ini adalah penelitian survei deskriptif (Notoatmodjo 2010) yaitu mendiskripsikan pengetahuan dan sikap ibu rumah tangga terhadap penggunaan Antibiotik di Desa Kuta Mbelin Kecamatan Lau Baleng Kababupaten Karo.

\section{Lokasi dan Waktu Penelitian}

Lokasi penelitian di Desa Kuta Mbelin Kecamatan Lau Baleng Kabupaten Karo. Penelitian dilakukan dari bulan Juni sampai bulan Juli 2014.

\section{Populasi dan Sampel}

Populasi pada penelitian ini seluruh ibu rumah tangga di Desa Kuta Mbelin Kecamaten Lau Baleng Kabupaten Karo. Jumlah populasinya sebanyak 250 orang.

Sampel penelitian ini adalah sebagian dari seluruh ibu rumah tangga yang menjadi target populasi. Teknik sampling yang digunakan dalam penelitian ini adalah secara acak sederhana (Simple Random Sampling). Berdasarkan tabel penentuan jumlah sampel dari populasi tertentu yang dikembangkan dari Isaac dan Michael (Sugiyono, 2012), yaitu untuk populasi 250, untuk taraf kesalahan $10 \%$ jumlah sampelnya adalah 130 .

\section{Cara pengumpulan data}

1. Data primer

Data primer diperoleh secara langsung dengan menggunakan kuesioner yang diberikan kepada responden yang telah berisi daftar pertanyaan serta pilihan jawaban yang telah disiapkan.

2. Data sekunder

Data sekunder dapat diperoleh dari kantor kepala desa di Desa Kuta Mbelin kecamatan Lau Baleng kab Karo.

\section{Pengolahan dan Analisis Data}

Pengolahan data dilakukan dengan melakukan tahapan sebagai berikut:

a. Editing

Langkah ini bertujuan untuk memperoleh data yang baik agar diperoleh informasi yang benar. Kegiatan yang dilakukan dengan melihat dan memeriksa apakah semua jawaban telah terisi.

b. Coding

Pemberian kode agar proses pengolahan lebih mudah, pengkodean didasari pada jawaban yang diberi skor atau nilai tertentu.

c. Tabulasi

Untuk melihat persentase dari setiap table, data bersifat deskriptif

Analisa data dilakukan dengan melihat jumlah responden dan persentase dari setiap jawaban, analisa bersifat deskriptif.

\section{Cara mengukur variabel}

\section{Pengetahuan}

Pengetahuan dapat diukur dengan menggunakan Skala Guttman (Sugiyono, 2012).

Nilai tertinggi tiap satu pertanyaan dalah 1, jumlah pertanyaan 10, maka nilai tertinggi setiap dari seluruh pertanyaan adalah 10 , pengetahuan dibagi menjadi 3 tingkat, yaitu

1. $76 \%-100 \%$ jawaban benar :pengetahuan baik

2. $56 \%-75 \%$ jawaban benar : pengetahuan cukup

3. $<56 \%$ jawaban benar : pengetahuan kurang 2. Sikap

Sikap diukur berdasarkan skala Likert. (Sugiyono, 2012). Nilai tertinggi tiap satu pertanyaan adalah 4 , jumlah pertanyaan 10 , nilai tertinggi seluruh pertanyaan adalah 40. Sikap dapat dibagi 3 tingkat, yaitu:

1. $76 \%-100 \%$ jawaban benar : sikap baik

2. $56 \%-75 \%$ jawaban benar : sikap cukup

3. $<56 \%$ jawaban benar: sikap kurang

Bobot setiap pertanyaan adalah sebagai berikut : Sangat setuju bobot 4, Setuju bobot 3, Tidak setuju bobot 2, Sangat tidak setujubobot 1

\section{HASIL DAN PEMBAHASAN}

Hasil

Profil Lahan

Desa Kuta Mbelin berada di Kecamatan Lau Baleng Kabupaten Karo. Batas-batas wilayahnya yaitu :

1. Sebelah Utara berbatasan dengan Desa Cerumbu

2. Sebelah Selatan berbatasan dengan Desa Kuta Kendit

3. Sebelah Timur berbatasab dengan Desa Pola Tebu

4. Sebelah Barat berbatasan dengan Desa Kuta Pengkih

Berdasarkan data yang diperoleh dari kantor Kepala Desa Kuta Mbelin, penduduk desa ini berjumlah 
956 orang yang terdiri dari laki-laki 453 orang dan perempuan 503 orang. Dan jumlah ibu rumah tangga yang berumur 20-50 tahun yaitu 250 orang. Pada umumnya Mata pencaharian penduduk di desa ini adalah petani dan wiraswasta. Luas Desa Kuta Mbelin adalah 5 hektar

\section{Karakteristik Responden}

Karakteristik responden yang diperoleh dari hasil wawancara meliputi umur, pendidikan dan pekerjaan.

Tabel 4.1 Distribusi Frekuensi Karakteristik Responden Menurut Umur

\begin{tabular}{ccc}
\hline Umur & $\begin{array}{c}\text { Jumlah } \\
\text { (orang) }\end{array}$ & $\%$ \\
\hline $20-25$ & 31 & 23,8 \\
$26-30$ & 30 & 23,1 \\
$31-35$ & 21 & 16,2 \\
$36-40$ & 23 & 17,7 \\
$41-45$ & 15 & 11,5 \\
$46-50$ & 10 & 7,7 \\
\hline Total & 130 & 100,0 \\
\hline
\end{tabular}

Dari tabel 4.1 distribusi frekuensi karakteristik responden menurut umur responden yang paling banyak adalah 20-25 tahun 31 orang $(23,8 \%)$ dan paling sedikit adalah umur 46-50 tahun 10 orang $(7,7 \%)$.
Tabel 4.2 Distribusi Frekuensi Karakteristik Responden Menurut Pendidikan

\begin{tabular}{ccc}
\hline Pendidikan & $\begin{array}{c}\text { Jumlah } \\
\text { (orang) }\end{array}$ & $\%$ \\
\hline SD & 11 & 8,5 \\
SMP & 33 & 25,4 \\
SMA & 70 & 53,8 \\
D3 & 12 & 9,2 \\
S1 & 4 & 3,1 \\
\hline Total & 130 & 100,0 \\
\hline
\end{tabular}

Dari tabel 4.2 dapat dilihat distribusi frekuensi karekteristik responden menurut pendidikan responden yang paling banyak adalah SMA 70 orang ( 53,8\%) dan paling sedikit adalah S1 4 orang $(3,1 \%)$.

Tabel 4.3 Distribusi Frekuensi Karakteristik Responden Menurut Pekerjaan

\begin{tabular}{ccc}
\hline Pekerjaan & Jumlah & $\%$ \\
\hline Ibu Rumah Tangga & 41 & 31,5 \\
Petani & 53 & 40,8 \\
Wiraswasta & 30 & 23,2 \\
Guru/PNS & 6 & 4,6 \\
\hline Total & 130 & 100,0 \\
\hline
\end{tabular}

Dari tabel 4.3 dilihat dari distribusi frekuensi karakteristik responden menurut pekerjaan responden yang paling banyak adalah petani 53 orang $(40,8 \%)$ dan ibu rumah tangga 41 orang $(31,5 \%)$ dan paling sedikit adalah Guru/PNS 6 orang $(4,6 \%)$.

\section{Pengetahuan Responden}

Tabel 4.4 Distribusi Frekuensi Pengetahuan Ibu Rumah Tangga Terhadap Penggunaan Antibiotik

\begin{tabular}{|c|c|c|c|}
\hline \multirow{2}{*}{ No. } & \multirow{2}{*}{ Pertanyaan } & \multicolumn{2}{|c|}{ Responden } \\
\hline & & Jumlah & $\%$ \\
\hline 1 & $\begin{array}{l}\text { Menurut ibu antibiotik merupakan obat yang dapat mengobati infeksi yang } \\
\text { disebabkan oleh bakteri } \\
\text { - Ya } \\
\text { - Tidak }\end{array}$ & $\begin{array}{c}116 \\
14\end{array}$ & $\begin{array}{l}89,20 \\
10,80\end{array}$ \\
\hline 2 & $\begin{array}{l}\text { Menurut ibu penggunaan antibiotik harus sesuai dengan petunjuk dokter } \\
\text { - Ya } \\
\text { - Tidak }\end{array}$ & $\begin{array}{c}127 \\
3\end{array}$ & $\begin{array}{c}97,70 \\
2,30\end{array}$ \\
\hline 3 & $\begin{array}{l}\text { Menurut ibu, penggunaan antibiotik yang diresepkan dokter harus dikonsumsi } \\
\text { sampai habis walaupun gejala infeksi sudah sembuh } \\
\text { - Ya } \\
\text { - Tidak }\end{array}$ & $\begin{array}{l}84 \\
46\end{array}$ & $\begin{array}{l}64.60 \\
35,40\end{array}$ \\
\hline 4 & $\begin{array}{l}\text { Menurut ibu penyakit influenza tidak dapat diobati dengan menggunakan } \\
\text { antibiotik } \\
\text { - Ya } \\
\text { - Tidak }\end{array}$ & $\begin{array}{l}50 \\
80\end{array}$ & $\begin{array}{l}38,50 \\
61,50\end{array}$ \\
\hline 5 & $\begin{array}{l}\text { Menurut ibu antibiotik merupakan obat yang tidak dapat mengobati infeksi yang } \\
\text { disebabkan virus } \\
\text { - Ya } \\
\text { - Tidak }\end{array}$ & $\begin{array}{l}64 \\
66\end{array}$ & $\begin{array}{l}49,20 \\
50,80\end{array}$ \\
\hline
\end{tabular}




$\begin{array}{llll}6 & \text { Menurut ibu antibiotik dapat menimbulkan efek samping } & 86 & 66,20 \\ & \bullet \quad Y a & 44 & 33,80 \\ & \bullet \quad \text { Tidak }\end{array}$

\begin{tabular}{|c|c|c|c|}
\hline 7 & $\begin{array}{l}\text { Menurut ibu antibiotik tidak dapat digunakan bersama kerabat sendiri yang } \\
\text { mempunyai penyakit yang sama } \\
\text { - Ya } \\
\text { - Tidak }\end{array}$ & $\begin{array}{l}68 \\
62\end{array}$ & $\begin{array}{l}52,30 \\
47,70\end{array}$ \\
\hline 8 & $\begin{array}{l}\text { Menurut ibu bahaya dari penggunaan antibiotik yang tidak tepat dapat } \\
\text { menyebabkan kuman kebal terhadap antibibiotik } \\
\text { - Ya } \\
\text { - Tidak }\end{array}$ & $\begin{array}{c}112 \\
18\end{array}$ & $\begin{array}{l}86,15 \\
13,84\end{array}$ \\
\hline 9 & $\begin{array}{l}\text { Menurut ibu antibiotik dapat menyebabkan keracunan jika digunakan melebihi } \\
\text { dosis yang diberikan dokter } \\
\text { - Ya } \\
\text { - Tidak }\end{array}$ & $\begin{array}{c}121 \\
9\end{array}$ & $\begin{array}{c}93,07 \\
6,92\end{array}$ \\
\hline 10 & $\begin{array}{l}\text { Menurut ibu penyimpanan antibiotik yang baik harus terhindar dari sinar } \\
\text { matahari } \\
\text { - Ya } \\
\text { - Tidak }\end{array}$ & $\begin{array}{c}124 \\
6\end{array}$ & $\begin{array}{c}95,38 \\
4,61\end{array}$ \\
\hline
\end{tabular}

Dari tabel 4.4 dapat dijelaskan bahwa responden mengetahui bahwa antibiotik merupakan obat yang dapat mengobati infeksi yang disebabkan oleh bakteri sebesar 116 orang yang menjawab ya $(89,20 \%)$. Responden juga mengetahui bahwa penggunaan antibiotik harus sesuai dengan petujuk dokter $(97,70 \%)$. Sebanyak 84 responden $(64,60 \%)$ menjawab ya tentang penggunaan antibiotik yang diresepkan dokter harus dikonsumsi sampai habis walaupun gejala infeksi sudah sembuh.

Namun pengetahuan responden tentang penyakit influenza tidak dapat diobati dengan menggunakan antibiotik masih kurang yaitu 50 responden menjawab ya $(38,50 \%)$ dan 80 responden menjawab tidak $(61,50 \%)$. Responden juga kurang mengetahui bahwa antibiotik merupakan obat yang tidak dapat mengobati infeksi yang disebabkan virus dapat dilihat dari sedikitnya responden yang menjawab ya yaitu 64 orang $(49,20 \%)$ dan yang menjawab tidak 66 orang $(50,80 \%)$.

Responden juga mengetahui bahwa antibiotik dapat menimbulkan efek samping $(66,20 \%)$, responden juga mengetahui bahwa antibiotik tidak dapat digunakan bersama kerabat sendiri yang mempunyai penyakit yang sama $(52,30 \%)$. Sebanyak $112(86,15 \%)$ responden mengetahui bahwa bahaya dari penggunaan antibiotik yang tidak tepat dapat menyebabkan kuman kebal terhadap antibibiotik. sebanyak $121 \quad(93,07 \%)$ responden mengetahui bahwa antibiotik dapat menyebabkan keracunan jika digunakan melebihi dosis yang diberikan dokter. Responden juga mengetahui bahwa penyimpanan antibiotik yang baik harus terhindar dari sinar matahari.

Tabel 4.5 Distribusi Frekuensi Tingkat Pengetahuan ibu rumah tangga terhadap penggunaan Antibiotik

\begin{tabular}{lcc}
\hline \multicolumn{1}{c}{ Pengetahuan } & Frekuensi (n) & Persen (\%) \\
\hline Baik & 54 & 41,54 \\
Cukup & 65 & 50 \\
Kurang & 11 & 8,46 \\
\hline
\end{tabular}

Berdasarkan tabel di atas, didapati pengetahuan responden pada kategori baik sebesar 41,54\%, pada kategori cukup sebesar $50 \%$ sedangkan kategori kurang sebesar $8,46 \%$. 


\section{Sikap Responden}

Tabel 4.6 Distribusi Frekuensi Sikap Ibu Rumah Tangga Terhadap Penggunaan Antibiotik

\begin{tabular}{|c|c|c|c|}
\hline \multirow{2}{*}{ No } & \multirow{2}{*}{ Pertanyaan } & \multicolumn{2}{|c|}{ Responden } \\
\hline & & Jumlah & $\%$ \\
\hline 1 & $\begin{array}{l}\text { Menurut ibu penggunaan antibiotik tidak boleh secara sembarangan tanpa resep dokter } \\
\text { - Sangat Setuju } \\
\text { - Setuju } \\
\text { - Tidak Setuju } \\
\text { - Sangat Tidak Setuju }\end{array}$ & $\begin{array}{c}64 \\
63 \\
1 \\
2\end{array}$ & $\begin{array}{c}49,23 \\
48,50 \\
0.76 \\
1,50\end{array}$ \\
\hline 2 & $\begin{array}{l}\text { Menurut ibu antibiotik tidak diperlukan untuk semua penyakit } \\
\text { - Sangat Setuju } \\
\text { - Setuju } \\
\text { - Tidak Setuju } \\
\text { - Sangat Tidak Setuju }\end{array}$ & $\begin{array}{c}18 \\
70 \\
34 \\
8\end{array}$ & $\begin{array}{c}13,80 \\
53,80 \\
26,20 \\
6,20\end{array}$ \\
\hline 3 & $\begin{array}{l}\text { Menurut ibu pemakaian obat antibiotik harus dihentikan apabila terjadi reaksi alergi } \\
\text { - Sangat Setuju } \\
\text { - Setuju } \\
\text { - Tidak Setuju } \\
\text { - Sangat Tidak Setuju }\end{array}$ & $\begin{array}{c}43 \\
79 \\
7 \\
1\end{array}$ & $\begin{array}{c}33,08 \\
60,76 \\
5,38 \\
0,76\end{array}$ \\
\hline 4 & $\begin{array}{l}\text { Menurut ibu wanita yang sedang hamil, menyusui, atau alergi terhadap antibiotik tertentu } \\
\text { harus laporkan kepada dokter yang memeriksa } \\
\text { - Sangat Setuju } \\
\text { - Setuju } \\
\text { - Tidak Setuju } \\
\text { - Sangat Tidak Setuju }\end{array}$ & $\begin{array}{c}56 \\
71 \\
1 \\
2\end{array}$ & $\begin{array}{c}43,08 \\
54,61 \\
0.80 \\
1,50\end{array}$ \\
\hline 5 & $\begin{array}{l}\text { Menurut ibu dosis dan lama penggunaan antibiotik yang di tetapkan oleh dokter harus } \\
\text { dipatuhi walaupun telah merasa sehat } \\
\text { - Sangat Setuju } \\
\text { - Setuju } \\
\text { - Tidak Setuju } \\
\text { - Sangat Tidak Setuju }\end{array}$ & $\begin{array}{l}32 \\
59 \\
28 \\
11\end{array}$ & $\begin{array}{c}24,60 \\
45,40 \\
21,50 \\
8,50\end{array}$ \\
\hline 6 & $\begin{array}{l}\text { Menurut ibu apabila penggunaan antibiotik menimbulkan gejala alergi atau infeksi yang } \\
\text { diobati tidak berkurang, maka perlu berkonsultasi kedokter lagi } \\
\text { - Sangat Setuju } \\
\text { - Setuju } \\
\text { - Tidak Setuju } \\
\text { - Sangat Tidak Setuju }\end{array}$ & $\begin{array}{c}64 \\
62 \\
3 \\
1\end{array}$ & $\begin{array}{c}49,20 \\
47.70 \\
2,30 \\
0,80\end{array}$ \\
\hline 7 & $\begin{array}{l}\text { Menurut ibu antibiotik harus dihabiskan sesuai jumlah dalam resep dokter (umumnya } \\
\text { minimal 3-4 hari) } \\
\text { - Sangat Setuju } \\
\text { - Setuju } \\
\text { - Tidak Setuju } \\
\text { - Sangat Tidak Setuju }\end{array}$ & $\begin{array}{c}40 \\
78 \\
12 \\
0\end{array}$ & $\begin{array}{c}30,80 \\
60 \\
9,20 \\
0\end{array}$ \\
\hline 8 & $\begin{array}{l}\text { Menurut ibu penggunaan antibiotik harus sesuai dengan mengikuti petunjuk takarannya, } \\
\text { jangan mengurangi atau menambahnya } \\
\text { - Sangat Setuju } \\
\text { - Setuju } \\
\text { - Tidak Setuju } \\
\text { - Sangat Tidak Setuju }\end{array}$ & $\begin{array}{c}61 \\
67 \\
2 \\
0\end{array}$ & $\begin{array}{c}46,92 \\
51,53 \\
1,53 \\
0\end{array}$ \\
\hline
\end{tabular}


9 Menurut ibu penggunaan antibiotik yang berlebihan dapat menimbulkan efek samping

- Sangat Setuju

- Setuju

- Tidak Setuju

- Sangat Tidak Setuju

10 Menurut ibu antibiotik tidak boleh di simpan untuk penggunaan penyakit lain pada masa yang akan datang

- Sangat Setuju

- Setuju

Dari tabel 4.6 responden memiliki sikap baik dilihat dari pernyataan responden sangat setuju $(49,20 \%)$ dan bahwa penggunaan antibiotik tidak boleh secara sembarangan tanpa resep dokter. Responden setuju sebanyak 70 orang $(53,80 \%)$ bahwa antibiotik tidak diperlukan untuk semua penyakit.

Sikap responden baik juga terhadap pemakaian obat antibiotik harus dihentikan apabila terjadi reaksi alergi yaitu setuju $(60,76 \%)$ sebanyak 79 responden. 71 responden setuju $(54,61 \%)$ bahwa wanita yang sedang hamil, menyusui, atau alergi terhadap antibiotik tertentu harus laporkan kepada dokter yang memeriksa. Sebesar 59 responden setuju $(45,40)$ bahwa dosis dan lama penggunaan antibiotik yang ditetapkan oleh dokter harus dipatuhi walaupun telah merasa sehat.

Dari 130 responden 64 responden sangat setuju $(49,20 \%)$ bahwa apabila penggunaan antibiotik menimbulkan gejala alergi atau infeksi yang diobati tidak berkurang, maka perlu berkonsultasi kedokter lagi dan 78 responden setuju $(60 \%)$ bahwa antibiotik harus dihabiskan sesuai jumlah dalam resep dokter (umumnya minimal 3-4 hari. Sikap baik yang ditunjukkan oleh responden terhadap penggunaan antibiotik harus sesuai dengan mengikuti petunjuk takarannya, jangan mengurangi atau menambahnya setuju $(51,53 \%)$ sebesar 67 orang.

Sebanyak 83 responden setuju $(63,84 \%)$ bahwa penggunaan antibiotik yang berlebihan dapat menimbulkan efek samping. 67 responden juga setuju $(48,46 \%)$ bahwa antibiotik tidak boleh disimpan untuk penggunaan penyakit lain pada masa yang akan datang.

Tabel 4.7 Distribusi Frekuensi Tingkat Sikap ibu rumah tangga terhadap penggunaan antibiotik

\begin{tabular}{ccc}
\hline Sikap & Frekuensi (n) & Persen $(\%)$ \\
\hline Baik & 85 & 65,38 \\
Cukup & 44 & 33,84 \\
Kurang & 1 & 0,78 \\
\hline
\end{tabular}

Berdasarkan tabel diatas, didapati sikap responden baik yang mempunyai persentasi sebesar 65,38\% sedangkan sikap dengan kategori cukup sebesar $33,84 \%$ dan $0,78 \%$ tergolong dalam kategori sikap kurang

\section{Pembahasan}

Berdasarkan tabel 4.4 dapat dilihat bahwa responden $(89,20 \%)$ mengetahui bahwa antibiotik merupakan obat yang dapat mengobati infeksi yang disebabkan oleh bakteri. Responden juga mengetahui $(86,15 \%)$ bahwa bahaya penggunaan antibiotik yang tidak tepat dapat menyebabkan kuman kebal terhadap antibiotik. Pengetahuan responden $(64,60 \%)$ cukup baik tentang penggunaan antibiotik yang diresepkan dokter harus dikonsumsi sampai habis walaupun gejala infeksi sudah sembuh. Sedangkan pengetahuan responden $(38,5 \%)$ tidak baik tentang penyakit influenza tidak dapat diobati dengan menggunakan antibiotik.

Berdasarkan hasil distribusi frekuensi pengetahuan ibu rumah tangga terhadap penggunaan antibiotik maka dapat disajikan hasil penelitian dalam tabel 4.5. Dimana responden yang memiliki pengetahuan baik sebesar $(41,54 \%)$, responden yang memiliki pengetahuan cukup sebesar (50\%) dan responden yang memiliki pengetahuan kurang sebesar $(8,46 \%)$. Dengan demikian dapat disimpulkan bahwa responden yang memiliki pengetahuan cukup lebih banyak daripada responden yang memiliki pengetahuan baik. Hal ini sama dengan penelitian lain dengan judul Karekteristik Masyarakat dan Penggunaan Antibiotik secara bebas di Kecamatan Medan Timur Kota Medan menunjukkan bahwa 50,5\% responden memiliki tingkat pengetahuan sedang tentang antibiotik dan terdapat hubungan bermakna antara penggunaan antibiotik secara bebas dengan tingkat pendidikan (Larasati, 2013).

Dari tabel 4.6 dapat dilihat bahwa 49,23\% responden sangat setuju dan $50 \%$ setuju bahwa penggunaan antibiotik tidak boleh secara sembarangan tanpa resep dokter. Sikap responden baik terhadap antibiotik juga ditunjukkan dengan $(30,8 \%)$ responden sangat setuju dan $80 \%$ setuju bahwa antibiotik harus dihentikan sesuai jumlah dalam resep dokter (umumnya minimal 3-4 hari). Responden 43,08\% sangat setuju $54,61 \%$ setuju bahwa ibu yang sedang hamil, menyusui atau alergi terhadap antibiotik tertentu harus melaporkan kepada dokter yang memeriksa.

Berdasarkan hasil distribusi sikap ibu rumah tangga terhadap penggunaan antibiotik maka dapat disajikan hasil penelitian dalam tabel 4.7 dimana responden yang memiliki sikap yang baik sebanyak 85 
orang $(65,38 \%)$ responden yang memiliki sikap cukup sebanyak 44 orang $(33,84 \%)$ dan responden yang memiliki sikap kurang 1 orang $(0,78 \%)$.

Dengan demikian dapat dikatakan bahwa responden yang memiliki sikap baik lebih banyak daripada responden yang memiliki pengetahuan cukup. Hal ini sama dengan penelitian lain dengn judul penelitian Tingkat pengetahuan dan sikap Mahasiswa Universiti Sains Malaysia kampus Kejuruteraan, Ibong Tebal, Pulau Pinang tentang Penggunaan Antibiotik menyatakan bahwa sebanyak $57 \%$ mempunyai sikap yang baik (Harahap, 2011).

Walaupun pengetahuan pada penelitian ini dalam kategori cukup sedangkan sikap baik hal ini bisa saja terjadi, karena sikap dapat dipengaruhi oleh beberapa faktor diantaranya pengalaman pribadi. Untuk dapat menjadi dasar pembentukan sikap, pengalaman pribadi haruslah meninggalkan kesan yang kuat. Karena itu sikap akan lebih mudah terbentuk apabila pengalaman pribadi tersebut terjadi dalam situasi yang melibatkan faktor emosional. Faktor lainnya adalah pengaruh orang lain yang dianggap penting. Pada umumnya individu cenderung memiliki sikap yang konformis atau searah dengan sikap yang dianggap penting. Kecendrungan ini dimotivasi oleh keinginan untuk berafiliasi dan keinginan untuk menghindari konflik dengan orang yang dianggap penting, faktor lainnya yaitu media massa. Dalam pemberitaansurat kabar maupun radio atau media komunikasi lainnya, berita yang seharusnya factual disampaikan secara obyektif cenderung dipengaruhi oleh sikap penulisnya, akibatnya berpengaruh terhadap sikap konsumen (Azwar,2005).

\section{SIMPULAN DAN SARAN}

\section{Simpulan}

Dari penelitian yang dilakukan dapat ditarik kesimpulan bahwa :

1. Tingkat pengetahuan ibu rumah tangga di Desa Kuta Mbelin Kecamatan Lau Baleng Kabupaten Karo terhadap penggunaan antibiotik, berada pada kategori baik sebanyak 54 orang $(41,54 \%)$, sedangkan pada kategori cukup sebanyak 65 orang $(50 \%)$ dan pada kategori kurang sebanyak 11 orang $(8,46 \%)$. Jadi pengetahuan ibu rumah tangga paling banyak berada pada kategori cukup.

2. Sikap ibu rumah tangga di Desa Kuta Mbelin kecamatan Lau Baleng Kabupaten Karo terhadap penggunaan antibiotik, berada pada kategori baik sebanyak 85 orang $(65,38 \%)$, sedangkan pada kategori cukup sebanyak 44 orang $(33,84 \%)$ dan pada kategori kurang sebanyak 1 orang $(0,78 \%)$. Jadi Sikap ibu rumah tangga paling banyak berada pada kategori baik.

\section{Saran}

1. Untuk meningkatkan pengetahuan ibu rumah tangga di Desa Kuta Mbelin Kecamatan Lau
Baleng Kabupaten Karo terhadap penggunaan antibiotik.

2. Diharapkan instansi kesehatan dapat melakukan sosialisasi dan penyuluhan di Desa Kuta Mbelin Kecematan Lau Baleng Kabupaten Karo.

3. Kepada peneliti berikutnya untuk melakukan penelitian ke desa-desa lain tentang penggunaan antibiotik.

\section{DAFTAR PUSTAKA}

Azwar., S. Sikap Manusia Teori dan Pengukuran. Liberty:Yogyakarta.,2005

Departemen Farmakologi dan Terapeutik Fakultas Kedokteran Universitas Indonesia., 2009. Farmakologi dan Terapi. Edisi V. Jakarta: Balai Penerbit FK UI.

Hardiana., 2011. Tingkat Pengetahuan dan Sikap Mahasiswa Universiti Sains Malaysia Kampus Kejuruteraan, Ibong Tebal, Pulau Pinang Tentang Penggunaan Antibiotik pada Tahun 2011

<http://repository.usu.ac.id/handle/123456789/31 332> [diakses tanggal 20 juli 2014]

Larassati, H., 2013. Karekteristik Masyarakat dan Penggunaan Antibiotik Secara Bebas di Kecamatan Medan Timur Kota Medan <http://repository.usu.ac.id/handle/123456789/38 $\underline{6937}>$ [diakses tanggal 20 juli 2014]

Moorthy ,Y.T., 2013. Gambaran Pengetahuan Masyarakat Terhadap Penggunaan Atibiotika di Puskesmas Padang Bulan Medan. $<$ http://repository.usu.ac.id/handle/123456789/40 566>[diakses tanggal 5 Juli 2014]

Notoatmodjo, S., 2003. Pendidikan dan Prilaku Kesehatan. Jakarta: PT Rineka Cipta

Notoatmodjo, S., 2007. Promosi Kesehatan dan Ilmu Perilaku. Jakarta: PT Rineka Cipta

Notoatmodjo, S., 2010. Metodologi Penelitian Kesehatan. Jakarta: PT Rineka Cipta

Pratama, M.A., Tingkat Pengetahuan Masyarakat Terhadap Pengugunaan Antibiotik di Kelurahan Sukamaju, Kecamatan Medan Johor, Kota Madya Medan,

<http://repository.usu.ac.id/handle/123456789/39 872> [diakses tanggal 5 Juli 2014]

Pulungan, Sahara., 2011. Tingkat Pengetahuan Tentang Antibiotika di Kalangan Mahasiswa Non Medis Universitas Sumatra Utara. <http://repository.usu.ac.id./bitstream/123456789 /3133215>[diakses tanggal 5 Juli 2014]

Sugiyono, 2012., Metode Penelitian Pendidikan pendekatan Kuantitatif, Kulitatif dan $R \& D$. Bandung: Alfabeta

Tjay, T.H., dan Rahardja, K., 2002. Obat-obat Penting.Edisi V. Jakarta: Elex Media Komputindo.

Utami,R.E., 2012. Antibiotika, Resisten RasionalitasTerapi 
Wawan., Dewi ., 2011. Teori \& Pengukuran Pengetahuan, Sikap, dan Perilaku Manusia, Yogyakarta. Muha Medika.

Werner, David.,Thuman, Carol., Maxwell, Jane., 2007. Ketika Tidak Ada Dokter Buku Panduan Perawatan Kesehatan Desa. Bogor. General Art.
Widodo,R.S.Si., 2004. Panduan Keluarga Memilih Dan Menggunakan Obat.Yogyakarta: Kreasi Wacana Widjajanti N., 2002. Obat-obatan. Yogyakarta: Kanisius 